\title{
Applying Recommendations to Align Competences, Methodology and Assessment in Telematics, Computing and Electronic Engineering Courses
}

\author{
Davinia Hernández-Leo, Verónica Moreno, Juan M. Dodero, Abelardo Pardo, \\ MariCarmen Romero-Ternero, Yannis Dimitriadis Senior Member, IEEE, Juan I. Asensio-Pérez
}

\begin{abstract}
The alignment between competences, teachinglearning methodologies and assessment is a key element of the European Higher Education Area. This paper presents the efforts carried out by six Telematics, Computer Science and Electronic Engineering Education teachers towards achieving this alignment in their subjects. In a joint work with pedagogues, a set of recommended actions were identified. A selection of these actions were applied and evaluated in the six subjects. The cross-analysis of the results indicate that the actions allow students to better understand the methodologies and assessment planned for the subjects, facilitate (self)regulation and increase students' involvement in the subjects.
\end{abstract}

Index Terms - Engineering Education, Competences, Methodologies, Alignment.

\section{INTRODUCTION}

$\mathrm{T}$ HE work done in recent years by the Spanish Higher Education system in order to meet the demands from the European Higher Education Area (EHEA from now on) has led to reflections on the institutional and academic organization of the centres, the curriculum and syllabus understood as the learning programme - and the subjects as working cores within that programme. From these work, new questions arise that lead to new reformulations so as to gradually improve the approach of the training based on competences [1].

These new challenges are fundamentally in line with getting a methodology that allows the training of the competences proposed in the subjects. In order to design activities and tasks that result enabling, meaningful and attractive to our students and, so as to achieve a greater consistency in general, there is the need to reflect about the subjects' assessment system. This reflection brings a complex and costly task that focuses on understanding, from the training, academic and organizational perspectives, the importance of the alignment between the three key

Davinia Hernández-Leo(*), Verónica Moreno, Universitat Pompeu Fabra, (*autora de contacto: C/Roc Boronat 13808018 Barcelona, España; Tel.: +34 935421428; Fax.: +34 935422517), davinia.hernandez@upf.edu, veronica.moreno@upf.edu

Juan M. Dodero, Universidad de Cádiz, juanma.dodero@uca.es

Abelardo Pardo, Universidad Carlos III de Madrid, abel@it.uc3m.es

MariCarmen Romero-Ternero, Universidad de Sevilla, mcromerot@us.es

Yannis Dimitriadis, Juan I. Asensio-Pérez, Universidad de Valladolid, yannis@tel.uva.es,juaase@tel.uva.es elements: competences, methodology and assessment. Holistically understanding a subject, or a set of these, depends on the nature of the subjects themselves. Our case stands in the context of the IEEE disciplines, and more concretely in the scope of Telecommunications Engineering, Computer Science and Electronic Technology. These subjects have evolved and have been articulated following the EHEA guidelines [2]-[3] (and other regulations towards the formulation of the Degree programmes) with the fundamental objective that the students develop a set of general and particular competences along all subjects.

The Spanish universities have already done several efforts to adapt their studies to EHEA. The Teaching Quality and Innovation Support Unit of the Polytechnic School (USQUID-ESUP) of the Universitat Pompeu Fabra has carried out various studies on this line that raised information about the profile of the freshmen [4], which, in turn, has helped in the design and assessment of the University Introduction Course [5]-[6]. If we observe the scenario from a national perspective, we realize that the efforts in this direction are also important and varied. These actions include a careful design of the new degrees [7], the study of the organization of subjects in modules [8], the provision of tools to design syllabuses and training activities [9]-[11], the implementation of teaching-learning active methodologies [12]-[13] based on collaborative learning techniques [14]-[17], [26]-[30], on projects [18]-[19], or on problems [20], and the formative and summative assessment of the student more and more oriented to competences [21][23].

In this paper, we present the experience carried out in different subjects within the IEEE scope where we have implemented different mechanisms to enhance, promote and entrench the relationship between competences, teaching methodologies and assessment systems $\left(\mathrm{C}^{*} \mathrm{M}^{*} \mathrm{~A}\right.$ from now on). The presented work is the result of a wider project within the Fund Program "Analyses and Studies", call of 2009, entitled "AlienaME, Competence Development in ICT Engineering Degrees: Aligning Teaching and Learning Methodologies with Assessment" [24] and coordinated by USQUID-ESUP. The working team included 5 pedagogues and 17 teachers of the engineering scope from 7 Spanish universities (in alphabetical order: Universitat Autònoma de Barcelona, Universidad de Cádiz, Universidad Carlos III de Madrid, Universitat Pompeu Fabra, Universitat Ramon Llull, Universidad de Sevilla and Universidad de 
Valladolid). The project's objectives were: (1) analyse the consistency of methodology and assessment with the competences to be achieved in each one of the subjects under study; (2) select those recommended actions that teachers consider optimal and feasible for its implementation in the corresponding subjects, providing a consistent and reliable process both in terms of implementation, monitoring and assessment; (3) apply such recommendations and evaluate their impact in terms of teachers' and learners' satisfaction. This work allowed the creation of 12 recommended actions of different nature and complexity [25]. In this article we present 6 cases where a selection of these recommendations has been applied during the 2009-2010 year.

The rest of the article is organized as follows. Section II explains the context and the methodology carried out in the development of this work. More concretely, we detail the recommended actions identified in the project AlineaME, the subjects where these have been applied, and the methodology used to apply them. Section III describes the development of the recommendations' implementation as well as the obtained results. Finally, section IV discusses the conclusions derived from the study.

\section{Working METHOdOLOGY AND RECOMMENDATIONS FOR THE $\mathrm{C}^{*} \mathrm{M} *$ A ALIGNMENT}

The study presented here is essentially organized and developed from a qualitative perspective, in combination with the detection of quantitative trends, in order to accommodate the objectives and objects of study, where the importance and influence of the context is remarkable [26].The ultimate goal of the research is to obtain the required know-how from which to establish some actionoriented guidelines. In other words, to improve the alignment processes between competences-methodologiesassessment $\left(\mathrm{C}^{*} \mathrm{M}^{*} \mathrm{~A}\right)$.

As said in Latorre, Del Rincón and Arnal (2005:92) [27], this is about a study aimed at educational practices. This type of analyses are essentially designed to contribute to solving problems or provide guidelines for the actions, therefore the final outcomes are the decisions and recommended actions rather than contributing to the creation of knowledge or theories. The studies developed from this perspective do not have their own methodology in the sense that they are based on methodologies mostly used in empirical-analytic and constructivist guidelines. In this regard, the research is hence based on a mixed approach.

According to the definition of Van Dalen (1990) [28] we can state that this is a study of interrelationships. Specifically it is an analysis of multiple cases that are explored both from the descriptive and interpretative perspectives [29]. And this essentially allows a more rigorous approach to the reality of the case studies that has allowed to establish proposals both at general level, aimed at improving the $\mathrm{C}^{*} \mathrm{M} * \mathrm{~A}$ alignment, and at individual level, address the idiosyncrasies of each case.

\section{A. Work Methodology}

The methodology followed throughout the process including the contextual analysis, design of recommended actions, the corresponding implementation, and the assessment - was based on a feedback approach between the teachers involved, pedagogues and the project coordination.
Given the mixed approach of the research, the data collection instruments contained items of different nature. These instruments were applied with software tools to systemize the process. Fig.1 depicts a schematic graph showing the methodology followed from the initial to the final stages.

There are six basic phases. The first one focuses on the literature search to contextualize the starting point and to envision "where one wants to go. "The second phase designs, validates and disseminates the first questionnaire that reflects all the elements about "what, how, why, which and when" the involved teachers work and assess. The third phase includes the design of the recommendations aimed at optimizing the starting situation in terms of consistency between $\mathrm{C}^{*} \mathrm{M} * \mathrm{~A}$ by agreement with the involved teachers.

Afterwards, the fourth phase applies the recommendations to the corresponding cases, collecting evidences in terms of satisfaction and success both from the faculty and students. The fifth phase focuses on the evaluation of the recommendations' implementation: data collection, analysis of results and conclusion drawing. Finally, the production and dissemination of the report allows the analysis of each subject context and leads to a reflection on the possible improvement in order to optimize the starting situation.

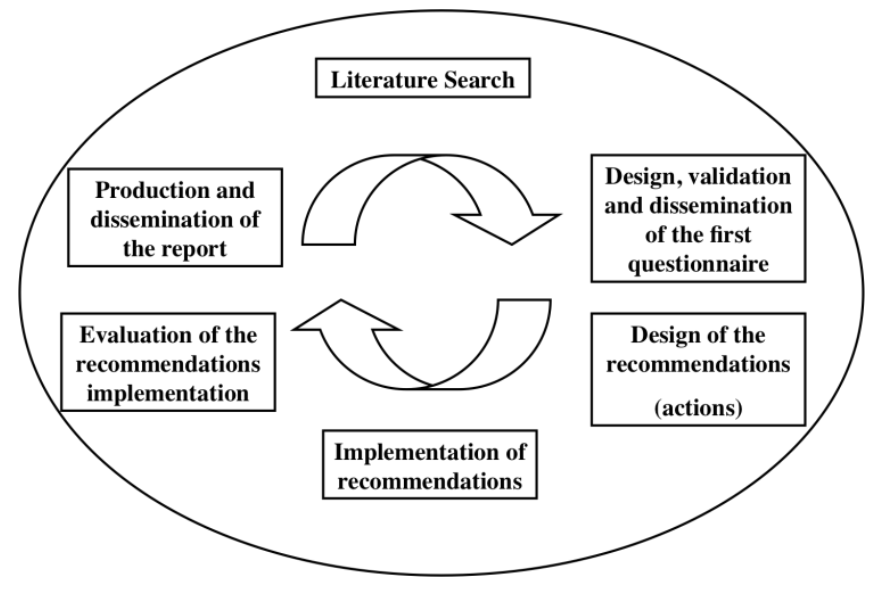

Fig. 1. Work Methodology

In the evaluation phase, apart from analysing the results for each case, we have done an overall assessment of the actions that have been common to more than one case. This crossed analysis has allowed us to obtain a contrasted view of the recommendations' effects.

\section{B. Recommendations}

The design of the recommendations arises from a process that begins with the collection of information about the key features of the subjects - competences, methodology, assessment system, etc. -in order to diagnose possible weaknesses (as well as strengths). As of this analysis, the approach of the recommendations is more contextualized to the cases so these can be analysed and evaluated by the teachers that will apply them. The second step that is carried out is to share the produced recommendations and provide space for discussion about their viability and consistency. This step took place in a meeting with the entire AlineaME project team where the members used group discussion dynamics involving not only teachers in the engineering field but also professionals of pedagogy. In addition to the analysis of 
recommendations, reflections emerged around how these processes could be carried out, what could be the drawbacks that teachers could face, and also the strengths of each recommendation. Following there is a brief summary of the guidelines or core aspects that are covered by all recommendations.

In general terms, the recommendations can be classified in 3 groups concerning: planning actions that have the greatest impact before the subject starts; planning and development activities that have the greatest impact during the development of the subject; and, finally, assessment actions that can be performed at the beginning, during or at the end of the training process.

1. Regarding the planning actions that have an impact before the course starts:

a. Compilation of "Best Practices" carried out in the area itself (even in related subjects) that are based on the alignment of $\mathrm{C}^{*} \mathrm{M}^{*} \mathrm{~A}$.

b. Strengthen, promote and establish communication channels with the teaching and research staff responsible of the subjects (especially considering the subjects that require certain competences related to others and vice-versa) to work cooperatively in the planning of competences (level acquisition by subject-course) as well as strategies to foster and evaluate such competences. This recommendation could involve a second action focused on reducing, levelling and distributing competences logically and consistently over the subject or degree (this can be done with "groups" of subjects). This way, the competence levels can be detailed and this actually helps facilitating their management in the design of the syllabuses.

c. Taking care of terminology. For example, talking about continuous assessment where labs, classroom activities, seminars, etc., have a weight in the evaluation, one should not use the word "exam", which has always stood for unique and final evaluation. It would be more appropriate to call it "test" or "individual practice with an evaluative nature".

d. Make the $\mathrm{C}^{*} \mathrm{M} * \mathrm{~A}$ alignment explicit in the syllabus and present it to students so they become aware of "what, how and why "they will work and will be evaluated.

2. As of recommendations that have a major impact during the development of the subject (although they assume a previous planning and organization work):

a. Virtuous Triangle: The student workload is a clear indicator that allows the teacher to see how much they work in alignment (both within and between subjects), so teachers should make an effort to determine the degree-intensity of each competence measuring the work required by an "average" student to carry out the proposed activities. From this point the teacher can regulate and adjust the methodological approach and assessment of each case. Figure 2 shows this "virtuous triangle" where all lines are discontinuous to emphasize the constant feedback and the permeability of the process.

b.Choosing, as much as possible, the work methodology according to the competence to work, and minimizing the effects of the resource limitations, group size, etc.

c. Combine different methodological techniques and strategies to make competence training broader so it reaches all students.

d. Verify that the projects are a substantial part of the $\mathrm{C}^{*} \mathrm{M} * \mathrm{~A}$ design. This practice is very common on engineering studies and, therefore, it is important to ensure that its approach-design responds consistently to the alignment sought.

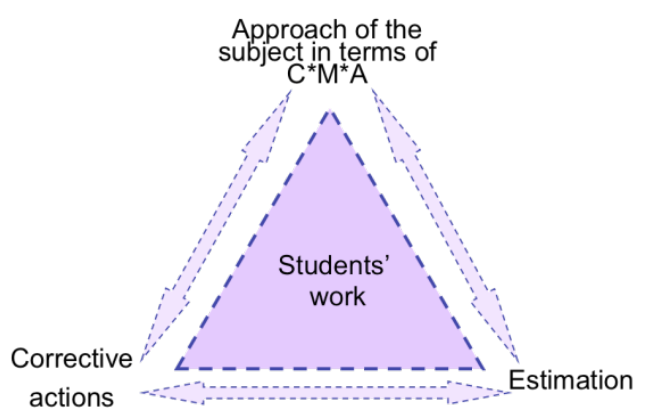

Fig. 2. Virtuous triangle.

3. And finally, those recommendations that refer to the processes that assess the competences.

a. Inquire about the level of competence of the students at the beginning of the subject. This way the teacher collects evidence from the starting point of the group and students become aware of their level of competence.

b. Include in the assessment process those transversal competences listed in the syllabuses. To do so, one can design small tools to collect evidence on their evaluation [30-32].

c. Design the assessment of the subject as a learning task-process and present it this way to the students.

As observed, within the general framework of the proposed recommendations we find a different depth range, understanding such depth as complexity and viability depending on the subject and its idiosyncratic characteristics. Six subjects have applied a sub-set of these recommendations in the 2009-2010 year. This work focuses on the recommendations 1.d, 2.a, 2.c and 3.a, as these are the most common in the subjects and hence those that allow us to draw crossed conclusions using the results obtained within each subject. In the following section we provide a more explicit detail on the implementation process. Before, we provide some details about the subjects participating in the study. 
TABLE I

DESCRIPTION OF THE INVOLVED SUBJECTS

\begin{tabular}{|c|c|c|c|c|c|c|}
\hline Subject & $\begin{array}{c}\text { TelematicsApplica } \\
\text { tions III (AT-III) }\end{array}$ & $\begin{array}{c}\text { Telematics } \\
\text { Complements II } \\
\text { (CT-II) }\end{array}$ & $\begin{array}{c}\text { Computer } \\
\text { Architecture and } \\
\text { Technology II } \\
\text { (ETC-II) }\end{array}$ & $\begin{array}{c}\text { Systems } \\
\text { Architecture } \\
\text { (AS) }\end{array}$ & $\begin{array}{c}\text { Web Engineering } \\
\text { (IWeb) }\end{array}$ & $\begin{array}{c}\text { Telematics } \\
\text { Systems on } \\
\text { Education and } \\
\text { Medicine (STEM) }\end{array}$ \\
\hline $\begin{array}{l}\text { Type of } \\
\text { subject, year, } \\
\text { credits }\end{array}$ & $\begin{array}{l}\text { Quarterly subject, 3rd } \\
\text { year, 4,5 ECTS, } \\
\text { Compulsory }\end{array}$ & $\begin{array}{l}\text { Quarterly subject,5th } \\
\text { year, 6LRU credits, } \\
\text { Optional }\end{array}$ & $\begin{array}{l}\text { Quarterly subject, } \\
\text { 1st year,7.5 LRU } \\
\text { credits, Core }\end{array}$ & $\begin{array}{l}\text { Quarterly subject, } \\
\text { 2nd year, 6 ECTS, } \\
\text { Compulsory }\end{array}$ & $\begin{array}{l}\text { Quarterly subject,4th } \\
\text { year, 4.5 LRU credits, } \\
\text { Optional }\end{array}$ & $\begin{array}{l}\text { Master quarterly } \\
\text { subject, 5 ECTS } \\
\text { (specialization on } \\
\text { "Telematics Systems") }\end{array}$ \\
\hline $\begin{array}{l}\text { Degree where } \\
\text { it is taught, } \\
\text { University } \\
\text { and enrolled } \\
\text { students }\end{array}$ & $\begin{array}{l}\text { Telecommunications } \\
\text { Engineering- } \\
\text { Telematics (Old } \\
\text { programme) } \\
\text { U. Pompeu Fabra } \\
34 \text { students }\end{array}$ & $\begin{array}{l}\text { Telecommunications } \\
\text { Engineering(Old } \\
\text { programme) } \\
\text { U. de Valladolid } \\
23 \text { students }\end{array}$ & $\begin{array}{l}\text { IT Engineering } \\
\text { Specialization on } \\
\text { Management (Old } \\
\text { programme) } \\
\text { U. de Sevilla } \\
80 \text { students }\end{array}$ & $\begin{array}{l}\text { Degrees on Telematics, } \\
\text { Communications } \\
\text { Systems and } \\
\text { Multimedia systems. } \\
\text { U. Carlos III de } \\
\text { Madrid } \\
40 \text { students }\end{array}$ & $\begin{array}{l}\text { Computer Engineering } \\
\text { U. de Cádiz } \\
15 \text { students }\end{array}$ & $\begin{array}{l}\text { TIC Research Master } \\
\text { U. de Valladolid } \\
12 \text { students }\end{array}$ \\
\hline $\begin{array}{l}\text { Concerning } \\
\text { the } \\
\text { competences } \\
\text { to work in the } \\
\text { subject }\end{array}$ & $\begin{array}{l}\text { Specific: design and } \\
\text { development of } \\
\text { telematics applications } \\
\text { with Servlets and JSPs } \\
\text { by accessing databases, } \\
\text { capacity to recognize } \\
\text { and justify the factors } \\
\text { involved in the } \\
\text { selection of } \\
\text { technologies and } \\
\text { products for the design } \\
\text { and development of } \\
\text { Web applications. } \\
\text { Transversal: oral and } \\
\text { written } \\
\text { communication, } \\
\text { planning and time } \\
\text { management, } \\
\text { teamwork, capacity to } \\
\text { apply knowledge to } \\
\text { practice. }\end{array}$ & $\begin{array}{l}\text { Specific: management } \\
\text { of networked } \\
\text { information systems, } \\
\text { technologies for } \\
\text { integrated management } \\
\text { of networked } \\
\text { information systems: } \\
\text { managing Internet, } \\
\text { Web-based } \\
\text { management. } \\
\text { Transversal: } \\
\text { reasoning skills, } \\
\text { concept relationship, } \\
\text { analysis and synthesis, } \\
\text { teamwork, } \\
\text { organization and } \\
\text { planning, oral and } \\
\text { written communication } \\
\text { in the field of } \\
\text { telecommunications } \\
\text { and electronics. }\end{array}$ & $\begin{array}{l}\text { Specific: related to the } \\
\text { cognitive aspects: } \\
\text { knowledge and } \\
\text { understanding of the } \\
\text { design and use of } \\
\text { digital systems. And } \\
\text { related to procedural } \\
\text { aspects: know-how, } \\
\text { design, building and } \\
\text { use digital systems. } \\
\text { Transversal: capacity } \\
\text { for analysis and } \\
\text { synthesis, problem } \\
\text { solving, teamwork, } \\
\text { capacity to apply } \\
\text { theory to practice. }\end{array}$ & $\begin{array}{l}\text { Specific: C } \\
\text { programming of } \\
\text { nontrivial applications, } \\
\text { industrial management } \\
\text { tools } \\
\text { Transversal: } \\
\text { Teamwork, self- } \\
\text { learning ability. }\end{array}$ & $\begin{array}{l}\text { Specific: methods, } \\
\text { techniques and tools } \\
\text { for Web application } \\
\text { development, } \\
\text { implementation of the } \\
\text { complete cycle of a } \\
\text { Web application } \\
\text { Transversal: } \\
\text { planning and } \\
\text { organizational skills, } \\
\text { teamwork, motivation } \\
\text { for quality and } \\
\text { independent learning. }\end{array}$ & $\begin{array}{l}\text { Research skills critical } \\
\text { attitude, writing and } \\
\text { communication, } \\
\text { innovative proposals, } \\
\text { etc. Within the specific } \\
\text { context of the } \\
\text { intersection in } \\
\text { Telematics and the } \\
\text { application domains } \\
\text { (Education and } \\
\text { Medicine). }\end{array}$ \\
\hline $\begin{array}{l}\text { Developed } \\
\text { activities } \\
\text { developed in } \\
\text { the subject }\end{array}$ & $\begin{array}{l}\text { This course combines } \\
\text { conducting a project } \\
\text { where the students, in } \\
\text { groups of three, must } \\
\text { design and develop a } \\
\text { Web application, with } \\
\text { individual activities to } \\
\text { resolve short practice } \\
\text { assignments and } \\
\text { analyse various Web } \\
\text { technologies and cases, } \\
\text { all in a collaborative } \\
\text { manner by use of } \\
\text { wikis, glossaries and } \\
\text { discussion forums. }\end{array}$ & $\begin{array}{l}\text { The students carried } \\
\text { out group activities in } \\
\text { the lab aimed at the } \\
\text { implementation, in a } \\
\text { controlled scenario, of } \\
\text { network management } \\
\text { applications based on } \\
\text { some of the } \\
\text { technologies discussed } \\
\text { in the first part of the } \\
\text { course. Each group } \\
\text { was asked to produce a } \\
\text { final report and an oral } \\
\text { presentation. }\end{array}$ & $\begin{array}{l}\text { Development of } 4 \text { team } \\
\text { activities applying } \\
\text { cooperative learning; } \\
\text { each one divided into } 4 \\
\text { tasks related to } \\
\text { planning, assimilation } \\
\text { of fundamental } \\
\text { concepts, practical } \\
\text { implementation and } \\
\text { presentation of the } \\
\text { work on a poster } \\
\text { format. The teacher } \\
\text { provides continuous } \\
\text { feedback using the } \\
\text { electronic group } \\
\text { portfolio. }\end{array}$ & $\begin{array}{l}\text { This subject uses a } \\
\text { strategy of active } \\
\text { learning with } \\
\text { continuous assessment. } \\
\text { Each session consists } \\
\text { of previous and in- } \\
\text { class activities. } \\
\text { The first half of the } \\
\text { course the practices are } \\
\text { conducted in pairs and } \\
\text { in the second half } \\
\text { working teams of } 4 \text { or } \\
5 \text { people are created. }\end{array}$ & $\begin{array}{l}\text { During the first part of } \\
\text { the course, the students } \\
\text { develop a series of } \\
\text { works in a wiki-based } \\
\text { collaborative } \\
\text { environment, focused } \\
\text { on learning new } \\
\text { methods and } \\
\text { development } \\
\text { environments, while in } \\
\text { the second part of the } \\
\text { course the teams } \\
\text { develop a Web project } \\
\text { at all phases of the } \\
\text { cycle life of software } \\
\text { engineering. }\end{array}$ & $\begin{array}{l}\text { It is based on case } \\
\text { studies and using } \\
\text { multiple collaborative } \\
\text { techniques. The } \\
\text { students analyse real } \\
\text { scenarios, related to } \\
\text { basic bibliography as } \\
\text { well as challenges for } \\
\text { R\&D\&I. The } \\
\text { evaluation is formative } \\
\text { and includes all the } \\
\text { generated artefacts as } \\
\text { peer review and self- } \\
\text { evaluation. The course } \\
\text { is based on a Wiki } \\
\text { platform and external } \\
\text { tools both individual } \\
\text { and collaborative. }\end{array}$ \\
\hline
\end{tabular}

\section{Subjects}

Table I shows the description of the subjects involved in the study, including details relating to the type of subject, the competences posed in each one and the proposed activities.

As seen in the table, the contextual features of the subjects (degree, year, number of students) are varied and represent a sample of the diversity of subjects in IEEE fields (Telematics, IT, Electronics) where we need to work towards the $\mathrm{C}^{*} \mathrm{M} * \mathrm{~A}$ alignment. In particular, the subjects that take part of the study are core, compulsory and optional subjects, ranging from 1 st to 5 th year and a Masters course. The number of students enrolled in each course varies from small groups of students (12-15) to large groups (80). The specific competences worked in the subjects depend on their particular specific areas, with a (partial) match in the case of AT-III and iWeb. Differently, there is a greater convergence in the case of transversal subjects. In particular, the most common competences are those related to teamwork, planning and time organization, or written and oral communication.

The characteristics of each subject have been important in the study when choosing the recommended actions to implement in each subject (see section III.A), including the preparation of the activities or works proposed to the students.

The last row of Table I provides the description of these proposed activities, including: the development of application following a project-based learning methodology, the preparation of technical reports, participation in discussions about the selection of appropriate technologies for case studies through asynchronous interaction tools (wikis, forums), oral presentations, lab sessions, analysis of information sources, and review of other students work. Additional details about the proposed works in the subjects can be found in [24]. 
TABLE II

OVERVIEW OF THE RECOMMENDATIONS IMPLEMENTATION AND EVALUATION PROCESSES

\begin{tabular}{|c|c|c|}
\hline $\begin{array}{c}\text { Recommendation } \\
\end{array}$ & Implementation & Evaluation \\
\hline $\begin{array}{l}\text { 1.d Make the } C * M * E \text { alignment } \\
\text { explicit in the teaching plans and } \\
\text { present it to students so they become } \\
\text { aware of "what, how and why" they } \\
\text { will work and will be evaluated } \\
\qquad \mathrm{n}=2 \text { subjects } \\
\text { (AT-III/ ETC-II) }\end{array}$ & $\begin{array}{l}\text { - Include elements in the syllabus that show the } \\
\mathrm{C}^{*} \mathrm{M}^{*} \mathrm{~A} \text { alignment and make them explicit in the } \\
\text { presentation of the plan to the students. }\end{array}$ & $\begin{array}{l}\text {-Ask students about their perception regarding the } \\
\text { usefulness of knowing the intentional relationship } \\
\text { between the three elements. }\end{array}$ \\
\hline $\begin{array}{l}\text { 2.a Virtuous Triangle } \\
\qquad \mathrm{n}=4 \text { subjects } \\
\text { (AT-III/ CT-II/ IWeb/ STEM) }\end{array}$ & $\begin{array}{l}\text {-Collection of data about the student's dedication } \\
\text { in scheduled activities. } \\
\text {-All students taking part in the activities. } \\
\text {-Per-activity systematization of feedback } \\
\text { regarding the dedication }\end{array}$ & $\begin{array}{l}\text { - Use instruments either specific for this purpose or by } \\
\text { means of the subject global evaluation process. }\end{array}$ \\
\hline $\begin{array}{l}\text { 2.c Combine different methodological } \\
\text { techniques and strategies to make } \\
\text { competence training broader so it } \\
\text { reaches all students } \\
\qquad \mathrm{n}=4 \text { subjects } \\
(\mathrm{AS} / \mathrm{AT}-\mathrm{III} / \mathrm{ETC}-\mathrm{II} / \mathrm{STEM})\end{array}$ & $\begin{array}{l}\text {-Reflect on which strategies and techniques can } \\
\text { better meet the objectives of the subject and the } \\
\text { scheduled activities. } \\
\text {-Raise several task-instrument/strategy } \\
\text { relationships, combining them so as to cover } \\
\text { several interpersonal competences or learning } \\
\text { styles. }\end{array}$ & $\begin{array}{l}\text {-Ask the students about their own assessment on } \\
\text { combining multiple strategies and techniques for the } \\
\text { subject evaluation. } \\
\text {-The teacher gathers observations and notes about it. }\end{array}$ \\
\hline $\begin{array}{l}\text { 3.a Inquire about the level of } \\
\text { competence of the students at the } \\
\text { beginning of the subject. In this way } \\
\text { the teacher collects evidence from the } \\
\text { starting point of the group and } \\
\text { students become aware of their level of } \\
\text { competence } \\
\qquad n=4 \text { subjects } \\
\qquad(\mathrm{AS} / \mathrm{AT}-\mathrm{III} / \mathrm{ETC}-\mathrm{II} / \mathrm{STEM})\end{array}$ & $\begin{array}{l}\text {-Introduce to the students the list of competences } \\
\text { so they can assess their development level in } \\
\text { each case, using rubrics, real examples or } \\
\text { professional contexts, etc. }\end{array}$ & $\begin{array}{l}\text {-Ask questions in the opinion questionnaire at the end of } \\
\text { the subject. } \\
\text {-Provide students with an open questions questionnaire } \\
\text { the last day of the subject. } \\
\text {-Gather comments and informal feedback made by } \\
\text { students. }\end{array}$ \\
\hline
\end{tabular}

\section{DEVELOPMENT AND RESUlTS}

This third section contains the most significant elements of implementation and evaluation of the recommendations, as well as the results obtained. To make it easier to read and given the amount of data collected, the information is again synthesized into tables.

\section{A. Implementation of Recommendations}

As mentioned before, although the implemented recommendations were common to several subjects, the process may have been different given the characteristics of each particular case. This is why Table II shows a summary relating each recommendation with the matching elements during its implementation onto the subjects, together with the evaluation process that was carried out.

Thus, the table reflects the fundamental elements of both the implementation process (instrumentation, resources, timing, etc.) and its evaluation impact. As it is noted, it mainly relates to the perceived satisfaction and usefulness from the students' perspective, complemented with the teachers observations and reviews. Given the nature of the study, and even if the same recommendations are used, the results in the different subjects do not necessarily have to match. Context components and idiosyncrasies of the subjects themselves may prove to be conditioning factors.

\section{B. Results}

Table III outlines the main results for the assessments and observations gathered during the process of implementation of the recommendations in the six subjects. In certain cases one can observe that the particular results differ between subjects. However, overall, the crossed outcomes show some trends indicating that the implemented actions manage to locate the students within the subjects and the corresponding methodological approach and evaluation.
This results into a more (self-)regulated training and a greater involvement of the students.

\section{CONCLUSION}

The work presented in this paper has been possible thanks to the joint reflection of teachers in the area of Telematics Engineering, Computer Science and Electronics and of pedagogical experts, who have debated, discussed and agreed upon actions to improve the alignment of competences, teaching-learning methodologies and assessment strategies raised in subjects of the engineering fields involved. The generation of recommended actions of diverse nature has allowed each teacher to adopt some of them according to criteria such as relevance, suitability to their context/subject as well as considering the feasibility and the available time vs. required time to implement the recommendation.

Among the instruments provided to collect evidence on the impact of the implementation of recommendations from the learner's perspective (especially in terms of satisfaction), different lessons learnt arise depending on the recommendation made. In the case of recommendations that focus on making explicit the perception of the $C^{*} M^{*} A$ alignment and comparing the previous competence levels to those acquired during the subject, the results indicate that these actions allow students to locate themselves within the subject, to understand the methodological approaches as well as to evaluate their own progress and reflect on important aspects of the competences addressed. On the other hand, actively estimating the students' workload in order to identify corrective actions in the $\mathrm{C}^{*} \mathrm{M}^{*} \mathrm{~A}$ approach results in providing a positive impact on the actual planning of courses and overall onto students. Finally, in the subjects 
TABLE III

CROSSED AND PER-SUBJECT RESUlts OF THE RECOMMENDATIONS IMPLEMENTATION

\begin{tabular}{|c|c|c|}
\hline Recommendation & Crossed Results & Per-subject results \\
\hline $\begin{array}{l}\text { 1.d Make the } C^{*} M^{*} A \\
\text { alignment explicit in the } \\
\text { teaching plans and present it } \\
\text { to students so they become } \\
\text { aware of "what, how and } \\
\text { why" they will work and } \\
\text { will be evaluated } \\
\qquad n=2 \text { subjects } \\
\qquad(\mathrm{AT}-\mathrm{III} / \mathrm{ETC}-\mathrm{II})\end{array}$ & $\begin{array}{l}\text {-At the end of course the general } \\
\text { feeling is that students have } \\
\text { perceived a better "rationale" of } \\
\text { the proposed activities. }\end{array}$ & $\begin{array}{l}\text {-Comments like the following one are observed in several cases: "The teaching } \\
\text { plan has been quite helpful to understand the approach of the subject, to better } \\
\text { organize the works and projects and the time dedicated to them." [AT-III] } \\
\text {-After the development of the subject, the teacher appreciates the recommendation } \\
\text { observing that students are more focused on the teaching-learning process. [ETC- } \\
\text { II] }\end{array}$ \\
\hline $\begin{array}{l}\text { 2.a Virtuous Triangle } \\
\qquad n=4 \text { subjects } \\
\text { (AT-III/ CT-II/ IWeb/ STEM) }\end{array}$ & $\begin{array}{l}\text {-It facilitates and encourages } \\
\text { student self-regulation in terms of } \\
\text { dedication, not only in the subject } \\
\text { concerned, but also reverts on } \\
\text { remaining subjects. } \\
\text { - The feedback allows corrections } \\
\text { (teacher estimation-real student } \\
\text { dedication) so as to improve the } \\
\text { development of the subject. } \\
\text {-A positive impact on the } \\
\text { competences of task planning and } \\
\text { in study time organization } \\
\text { (making explicit the intention to } \\
\text { continue working this in future } \\
\text { subjects-years). }\end{array}$ & $\begin{array}{l}\text {-The students suggest that the analysis of time/dedication is helpful for other } \\
\text { courses or subjects, but not so much for the on-going one. One student stated that } \\
\text { there should be a transversal subject to learn how to make these estimates and } \\
\text { assess competencies in a subject that includes working on a project } \\
\text { (planning/organization). [IWeb] } \\
\text {-Measuring the workload has helped the students to better organize their working } \\
\text { time within the subject. [CT-II] } \\
\text {-The teacher has noticed that the regulations regarding the dedication time have led } \\
\text { to an increase in the quality of the works and projects carried out by students } \\
\text { compared to previous years. [AT-III] } \\
\text {-The fact of knowing the average load of the working group is considered useful or } \\
\text { very useful to students. [CT-II] } \\
\text {-83\% of students who responded to the evaluation questionnaire claim to have } \\
\text { perceived some improvement (understanding this as rebalancing) in terms of the } \\
\text { workload of the course. Also, } 66.7 \% \text { said that it was helpful to better manage their } \\
\text { time. [STEM] }\end{array}$ \\
\hline $\begin{array}{l}\text { 2.c Combine different } \\
\text { methodological techniques } \\
\text { and strategies to make } \\
\text { competence training } \\
\text { broader so it reaches all } \\
\text { students } \\
\qquad n=4 \text { subjects } \\
\text { (AS/ AT-III/ ETC-II/ STEM) }\end{array}$ & $\begin{array}{l}\text {-Increase of the student's } \\
\text { involvement and greater } \\
\text { motivation towards the proposed } \\
\text { activities. } \\
\text {-The teachers can evaluate the } \\
\text { potential and constraints of each } \\
\text { competence training technique. } \\
\text {-Risk of feeling a greater workload } \\
\text { as the number of techniques to } \\
\text { collect learning evidences } \\
\text { increases. }\end{array}$ & $\begin{array}{l}\text { - Teacher satisfaction with the result obtained from the combination of } \\
\text { methodology and evaluation techniques applied. [AT-III] } \\
\text {-About } 70 \% \text { of students who completed the questionnaire provided positive } \\
\text { comments on this regard (especially because of the motivational component that } \\
\text { this new way of working represents). Occasionally, comments regarding the } \\
\text { inability of spending all the time they should were also collected. [AT-III] } \\
\text {-The students state to be more involved in the subject and that they have learned to } \\
\text { coordinate with the teammates after getting used to the new way of working. } \\
\text { [ETC-II] } \\
\text {-The teacher assessments through observations and data from student performance } \\
\text { are positive. [STEM] } \\
\text {-Working using a variety of techniques/strategies allows to value the strengths and } \\
\text { weaknesses of each one of them, especially those related to team-work. [AS] }\end{array}$ \\
\hline $\begin{array}{l}\text { 3.a Inquire about the level of } \\
\text { competence of the students } \\
\text { at the beginning of the } \\
\text { subject. In this way the } \\
\text { teacher collects evidence } \\
\text { from the starting point of } \\
\text { the group and students } \\
\text { become aware of their level } \\
\text { of competence } \\
\qquad n=4 \text { subjects } \\
\text { (AS/ AT-III/ ETC-II/ STEM) }\end{array}$ & $\begin{array}{l}\text {-It is useful to inquire about their } \\
\text { competence at different points } \\
\text { along the course in order to locate } \\
\text { themselves in the right scope, } \\
\text { assess their progress and reflect } \\
\text { on important aspects of the } \\
\text { competences covered }\end{array}$ & $\begin{array}{l}\text { - The teacher considers that a high percentage of students do not understand what } \\
\text { competences really mean and, in most cases, they sound distant to them. In any } \\
\text { case, making them aware of what they know before and after results satisfactory in } \\
\text { most cases. [ETC-II] } \\
-83 \% \text { of students bring positive comments in this regard emphasizing motivation } \\
\text { and reflection on their progress throughout the subject. [AT-III] } \\
\text {-The repetition of self-assessment of competences in three stages along the subject } \\
\text { is considered as the most valuable. The teacher used the last session to discuss } \\
\text { some of the "hard" competences as those relating to "multidisciplinary" work, the } \\
\text { "critical sense" or "societal and ethical implications". [STEM] } \\
\text { - The students agree that "The fact of reflecting at this level makes it clear what to } \\
\text { be expected from us and the potential progress made on the basis of each one of } \\
\text { the objectives established in the subject." [AS] }\end{array}$ \\
\hline
\end{tabular}

Ramon Llull), R. García (U. de Sevilla), B. Rubia, E.

under study we can see that the actions regarding the combination of different methodological techniques have a positive effect on the motivation and involvement of the students.

\section{ACKNOWLEDGEMENTS}

The recommendations that have been implemented in these subjects are the result of the work of the entire team shaped to develop the project for Studies and Analysis funded by the Spanish Ministry of Education "AlienaME, Competence Development in ICT Engineering Degrees: Aligning Teaching and Learning Methodologies with Assessment" (EA2009-0072): A. Barrera, E. Martí, M. Martínez (U. Autònoma de Barcelona), G. Rodríguez (U. de Cádiz), C. Delgado, A. Pardo (U. Carlos III de Madrid), A. Díaz, Xavier Binefa, V. Daza, A. Frangi, C. Martín, E. Peig, G. Piella, P. Santos (U. Pompeu Fabra), L. Vicent (U.
Villasclaras (U. de Valladolid). Eduard Bonada has edited the English version of this paper. To all of them, thanks for their involvement and dedication.

\section{REFERENCES}

[1] A. Navío,"Propuestas conceptuales en torno a la Competencia Profesional,"Revista de Educación, no. 337, pp 213-234, 2005.

[2] P. Sánchez, J. Gairín. "Planificar la formación en el Espacio Europeo de Educación Superior," ICE de la Universidad Complutense de Madrid, Madrid , 2008.

[3] SENA, "Metodología para la elaboración de normas de competencia laboral,"Bogotá: Dirección de Empleo.

[4] V. Moreno, J. Bellalta, J. Infante, G. Piella, A. Frangi,"El perfil del estudiantado recién llegado a la Ingeniería telecomunicación e Informática,"Proceedings of II Jornadas Internacionales UPM sobre Innovación Educativa y Convergencia Europea 2008. December 911, Madrid, 2008.Available inhttp://www.usquidesup.upf.edu/sites/default/files/publicaciones/Co m.CIU-CIOIE 08-09.pdf

[5] V. Moreno, A. Frangi, B. Bellalta, G. Piella, J. Infante. "El Curso de Introducción a la Universidad como a estrategia organizativa para acercar a los estudiantes de nueva incorporación a la Esuela Superior 
Politécnica,"Proceedings of $X$ Congreso Interuniversitario de Organización de las Instituciones Educativas. Desember 11-13, Barcelona, 2008. Available in http://www.usquidesup.upf.edu/sites/ default/files/publicaciones/ Com.CIU-CIOIE_08-09.pdf

[6] V. Moreno, A. Frangi, B. Bellalta, G. Piella, J. Infante,"Evaluación del Curso de Introducción a la Universidad,"Proceedings ofII Jornadas Internacionales UPM sobre Innovación Educativa y Convergencia Europea 2008.December 9-11, Madrid, 2008. Available

inhttp://www.usquidesup.upf.edu/sites/default/files/publicaciones/Co m.CIU-INECE 08-09.pdf

[7] D. Hernández-Leo, V. Moreno, Y. Dimitriadis, J.I. Asensio, "Hacia la alineación entre Competencias-Metodología-Evaluación en asignaturas de Ingeniería Telemática,"Proceedings ofJornadas de Innovación Educativa en Ingeniería Telemática,"Valladolid, September $\quad 30,2008$ Availableinhttp://www.usquidesup.upf.edu/sites/default/files/ publicaciones/alineame-2010-jie.pdf

[8] V. Moreno, D. Hernández-Leo, "Evaluación de la Estructura Modular en la Escuela Superior Politécnica. Primera Aproximación," Proceedings ofII Jornadas de Id-TIC 2009. 21- 22 de Abril, Madrid. Available in http://www.usquidesup.upf.edu/sites/default/ files/publicaciones/idTIC 2009.pdf

[9] V. Moreno, D. Hernández-Leo. "Creación de materiales con soporte Web para la mejora de la función docente en la Escuela Superior Politécnica - Universidad Pompeu Fabra,"Quaderns Digitals, vol. 63, 2010.

[10] I.M. Jorrín, B. Rubia, V. García Pérez, "Bersatide: Una herramienta web para generar diseños educativos basados en los principios del CSCL," Proceedings of Jornadas Universitarias de Tecnología Educativa, Santiago de Compostela, July 2006.

[11] A. Martínez, C. Hernández, C.E. Vivaracho, A. Simón, G. Arranz, M. Martínez. "Introducción de metodologías activas en la enseñanza de la informática: Experiencia del Grupo Greidi”. Proceedings of XII Jornadas sobre la Enseñanza Universitaria de la Informática, 347 354, Bilbao, July 2006.

[12] R. García. "Usando IMS-LD para diseñar escenarios pedagógicos en Ingeniería Informática,"Proceedings of European Conference LAMS, Cádiz, June 2008.

[13] R. Hernandez, A. Pardo, C. Delgado Kloos. "Creating and Deploying Effective eLearning Experiences Using LRN". IEEE Transactions on Education, 50(4):345-351, November 2007.

[14] D. Hernández-Leo, E.D. Villasclaras, I.M. Jorrín Abellán, J.I. Asensio Pérez, Y. Dimitriadis, I. Ruiz Requies, B.Rubia. "Collage, a Collaborative Learning Design Editor Based on Patterns Special Issue on Learning Design,"Educational Technology \& Society, 9(1):58-71, 2006.

[15] D. Hernández-Leo, J.I. Asensio Pérez, Y. Dimitriadis. "Collaborative learning strategies and scenario-based activities for understanding network protocols", Proceedings of 36th ASEE/IEEE Frontiers in Education Conference, S2F, FIE, 19-24, San Diego, CA, October 2006.

[16] D. Hernández-Leo, M.L. Bote Lorenzo, J.I. Asensio Pérez, E. Gómez Sánchez, E.D. Villasclaras Fernández, I.M. Jorrín Abellán, Y. Dimitriadis."Free- and Open Source Software for a Course on network Management: Authoring and Enactment of Scripts based on Collaborative Learning Strategies." IEEE Transactions on Education, 50(4):292-301, 2007.

[17] A. Martínez, E. Gómez, Y. Dimitriadis, I.M. Jorrín, B. Rubia, G. Vega. "Multiple Case Studies to Enhance Project-Based Learning in a Computer Architecture Course, " IEEE Transactions on Education, 48(3):482-489, 2005.

[18] F. Miralles, C. Guillamón. "ABP y metodologías activas para el desarrollo de competencias: Satisfacción de los estudiantes y mejora continua. El caso de Ingeniería de Telecomunicación en la UPF,"Proceedings ofIV Congreso Internacional Docencia Universitaria e Innovación (CIDUI), Barcelona, 5-8 July, 2006.

[19] E. Martí, D. Gil, M. Vivet, C. Julià. "Balance de cuatro años de experiencia en la implantación de la metodología de Aprendizaje Basado en Proyectos en la asignatura de Gráficos por Computador en Ingeniería Informática,"Proceedings of VIII Jornadas de Innovación Universitaria, Madrid, September 2008

[20] P. Muñoz, C. Delgado, C. "A software player for providing hints in problem-based learning according to a new specification," Computer Applications in Engineering Education, 17(3):272-284, 2009.

[21] D. Boud, N. Falchikov. "Rethinking assessment in higher education," Routledge, London, 2007.

[22] S. Bloxham, P. Boyd. "Developing effective assessment in higher education. A Practical Guide,” Open University Press, London, 2007.
[23] S. Brown, A. Glaser,"Evaluar en la Universidad. Problemas y nuevos enfoques."Nancea, Madrid, 2003.

[24] D. Hernández-Leo, V. Moreno, A. Díaz. "Memoria completa del proyecto AlineaME: Desarrollo de competencias en los grados TIC: Alineación de metodologías de enseñanza-aprendizaje con la evaluación, "Programa de Estudios y Análisis 2009. Ministerio de Ciencia e Innovación (EA2009/0072). Available in: http://82.223.210.121/mec/ayudas/repositorio/20100928143305Mem oriaFinalEA2009-0072.pdf

[25] D. Hernández-Leo, V. Moreno. "Recomendaciones, problemáticas y otras reflexiones sobre la alineación entre competencias, metodología y evaluación". Report of the project AlineaME.Available inhttp://www.usquidesup.upf.edu/sites/default/files/AlineaMEInforme-resultado-reunion-enero2010.pdf

[26] A. Salgado Levano,"Investigación cualitativa: diseños, evaluación del rigor metodológico y retos". liber., 2007, vol.13, no.13, p.71-78, 2007.

[27] A. Latorre, D. Del Rincon, J. Arnal. "Bases metodológicas de la investigación educativa", Ediciones Experiencia, Madrid, 2005.

[28] D. B. Van Dalen. "Manual de técnica de la investigación educacional".Paidós, México, 1990.

[29] R. Bisquerra. "Metodología de la investigación educativa", $L a$ Muralla, Madrid,2004.

[30] M. A. Sicilia, "How Should Transversal Competence Be Introduced In Computing Education", Inroads SIGCSE Bulletin, 41(4):95-98, 2009.

[31] M.C. Romero. "Una experiencia combinando AC y otras herramientas de aprendizaje en Estructura y Tecnología de Computadores,"Proceedings of IX Jornada sobre Aprendizaje Cooperativo (JAC09) y la II Jornada sobre Innovación en la Docencia (JID09), Universidad de Almería, España, 8-10 July 2009.

[32] M.C. Romero. "A case study: role-playing and cooperative learning in digital systems, "Proceedings of ENMA Education 2009 International Conference, Bilbao, España, 17-19 June 2009.

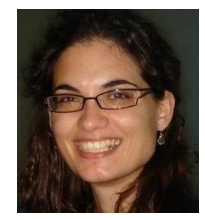

Davinia Hernández-Leo received the M.S. and the Ph.D. degrees in Telecommunications Engineering from the University of Valladolid. Her research interests include the application of technologies and telematics in Education, mainly focusing on ComputerSupported Collaborative Learning. She has several research awards and more than 50 publications on this field. She has been an assistant (non-PhD) professor at the Universidad de Valladolid, and she is currently an assistant $(\mathrm{PhD})$ professor at the Universitat Pompeu Fabra, where she also coordinates the Teaching Quality and Innovation Support Unit of the Polytechnic School. Davinia has received awards for her teaching and has participated and coordinated several Higher Education teaching innovation projects.

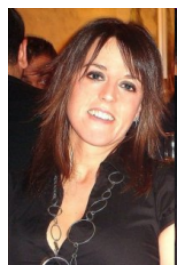

Verónica Moreno Oliver holds a degree on Pedagogy from the Universitat Autónoma de Barcelona, where she worked for four years supporting the "Pilot Plan for adaptation to the European Higher Education Area" in the degree of Pedagogy. She received the Master Oficial de Investigación en Educación (UAB) with a final master thesis about a methodological proposal for the definition of a professional profile for superior education, concretely an IT engineer. She is currently working on her $\mathrm{PhD}$ thesis focused on the analysis and intervention about the alignment between the competence training, strategy methodology and the assessment system in the university system. Since 2008, she is a part of the Teaching Quality and Innovation Support Unit of the Polytechnic School of the Uiniversitat Pompeu Fabra.

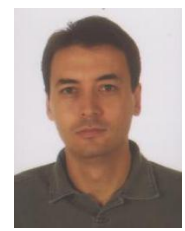

Juan Manuel Dodero holds a $\mathrm{PhD}$ in Computer Science from the UC3M. His research interests focus on web engineering, with special dedication to their applications for computer-assisted learning, areas where he has published several papers. He has worked as R \& D Engineer, as UC3M professor and is currently an associate professor at the Universidad de Cádiz. He participated, coordinated and evaluated various teaching innovation projects in the field of Engineering Education. He is also a founding member of the Spanish chapter of the ACM SIGCSE. 


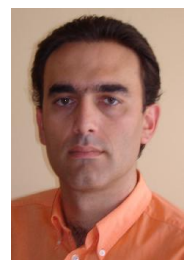

Abelardo Pardo is a computer engineer from the Universitat Politècnica de Catalunya (1991), and holds a $\mathrm{Ph} . \mathrm{D}$. in Computer Science from the University of Colorado (1997). Since 2000 he is an Associate Professor in the Department of Telematics Engineering at the University Carlos III of Madrid. He has participated in several projects both internationally (Genius, E-LANE, ICOPER) and nationally (ALWAYS, MOSAIC, Learn3). He has three years of experience in computer companies such as Mentor Graphics Inc. and AT \& T Bell Labs. The projects where he has participated relate to technology-supported learning, intelligent tutoring, computer-assisted learning and collaborative learning in virtual environments. His current interests are in the area of collaborative learning, adaptive hypermedia and computer-assisted learning.

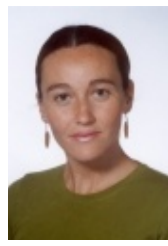

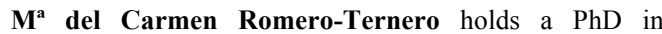
Computer Science and she is currently a professor at the Department of Electronic Technology at the Universidad de Sevilla and a member of the Research Group in Industrial Electronics and Computer Technology. Her research focuses on the application of multi-agent technology in distributed environments and the implementation of collaborative learning techniques in university classrooms, fields in which she has published several papers. She is a member of IEEE and ACM. She is currently Assistant Director of Infrastructure and Equipment of IT School in the University of Sevilla.

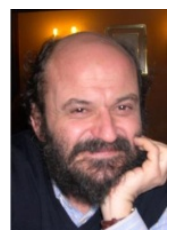

Yannis Dimitriadis studied Telecommunications Engineering at the National Technical University of Athens (Greece), at the University of Virginia (USA) and the University of Valladolid, where he is currently a Full Professor. His research focuses on telematics support to teaching/learning, for both the students and practitioners/teachers. He coordinates the interdisciplinary group GSIC/EMIC since 1994 with the participation of researchers and practitioners from both the field of technology (telematics and informatics) and of education. He teaches and coordinates the Master's Degree in ICT Research and the $\mathrm{PhD}$ in Telecommunications Technology from the University of Valladolid.

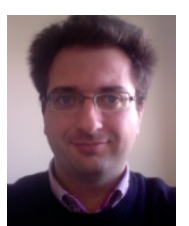

Juan Ignacio Asensio Pérez is a Telecommunications Engineer and $\mathrm{PhD}$ from the Universidad de Valladolid, where he is currently a Full Professor in the Department of Signal Theory and Communications and Telematics Engineering of the ETS Telecommunication Engineering. His research focuses on technology supported learning with special emphasis on computer-supported collaborative learning (CSCL). He is also currently Assistant Director for Academic Affairs at the Telecommunication Engineering School at the University of Valladolid. 